\title{
CAPITAL MARKET'S REACTION TOWARDS 2014 WORKING CABINET ANNOUNCEMENT (INDONESIAN CASE STUDY)
}

\author{
Anindya Ardiansari, $\bowtie$ Arif Saputra \\ Fakulty of Economics, Universitas Negeri Semarang, Semarang, Indonesia
}

\section{Info Artikel}

Sejarah Artikel:

Diterima Januari 2015

Disetujui Februari 2015

Dipublikasikan Maret 2015

Keywords:

Effectiveness;

Adaptive Leadership;

Job Satisfaction;

Commitment

\begin{abstract}
The purpose of this study is to examine the market reaction regarding the announcement of working cabinet following the election of Jokowi as the President of Indonesia. Political events such as presidential election, government change, cabinet announcement, and other events are very influential towards price and trade volume at the stock exchange since the political events are closely related to the state economy stability. The Sample in this study is stock which was listed as issuers in Indonesia Stock Exchange (IDX) which included in LQ45 company group during this research period from 20 October-3 November 2014 . The result shows that there was significant effect towards abnormal return difference before and after the cabinet announcement on the companies listed in LQ 45. The existence of this significant difference means that market reacted with the cabinet announcement event.
\end{abstract}

\section{REAKSI PASAR MODAL TERHADAP PENGUMUMAN KABINET 2014 (STUDI KASUS INDONESIA)}

\begin{abstract}
Abstrak
Penelitian ini bertujuan untuk menguji reaksi pasar khususnya investor di pasar modal terhadap penguman kabinet di pemerintahan presiden Jokowi. Kejadian politik seperti pemilu presiden, pemilihan legislatif, pemilihan gubernur, pengumuman kabinet, dan kejadian-kejadian lain nasional sangat berpengaruh terhadap harga dan volumen perdagangan di bursa saham. Sampel dalam penelitian ini adalah saham dari perusahaan yang terdaftar di BEI yang masuk dalam LQ45 selama periode 20 Oktober-3 November 2014. Hasil penelitian menunjukkan bahwa terdapat perbedaan signifikan abnormal return pada saat sebelum dan sesudah pengumaman kabinet dilakukan. Keberadaan abnormal return menunjukkan bahwa investor terpengaruh oleh situasi politik.
\end{abstract}

JEL Classification: M2, M20

\footnotetext{
Alamat korespondensi : 
Anindya Ardiansari \& Arif Saputra / Capital Market's Reaction Towards 2014 Working...

\section{INTRODUCTION}

Capital market is the place for companies to improve their long term needs by selling stock or issuing bond (Jogiyanto, 2003). As economic instrument, capital market cannot be separated from a variety of environmental influences, both economic and non-economic environment.

In the year 2014, Indonesian people celebrated their national democracy party by having a national General Election which is scheduled once in every five year. Two pairs of candidates passed the verification stage, they were Prabowo Subiyanto with Hatta Radjasa and Joko Widodo with Jusuf Kalla. After the simultaneous general election all over Indonesia, Joko Widodo and Jusuf Kalla has finally chosen as the elected President and Vice President of the Republic of Indonesia for 2014-2019 period with 53.15 percent votes defeating the number one pair candidate Prabowo Subiyanto and Hatta Radjasa with 46.85 percent (KPU).

After being pledged as the President of the Republic of Indonesia, President Joko Widodo has to announce his cabinet with ministers that will assist him in doing the duties. The cabinet announcement which later named "Working Cabinet" has gone through quite long and complicated process before finally formed. The announcement has also emerged polemic in the society for the government did not immediately announce the cabinet members soon after the inauguration on 20 October 2014. At first, the announcement would be held in Tanjung Priuk Port on 22 October 2014, but then canceled with no certain reason. The cancelation caused negative stigma within the society about the cabinet.After being announced on 27 October 2014, the Working Cabinet was filled with 34 ministers composition consisted of 21 professionals (nonparty) and 13 from the political party.

Political events such as presidential election, legislative election, government change, cabinet announcement, political chaos, war and other events are very influential towards price and trade volume at the stock exchange since the political events are closely related to the state economy stability. Furthermore, the political events might also cause negative trust from the investor. Political events which threaten the state stability tend to receive negative response from the market investors (Pronayuda, 2006).

Thus, the announcement of the ministerial cabinet by the President of Republic of Indonesia is a defining moment for the Indonesian that it isveryimportant to be watched and observed. The event might influence the Indonesian state for the cabinet is a group of ministers with state duties responsibility along with the president who will bring the country to the better direction.

The political condition, directly and indirectly, will affect the economy situation of a country. When the situation is conducive, the economy will tend to be stable and develop. Conversely, the volatility of economy situation will disturb the economy as the investors are not dare enough to invest due to the higher risk which might come. Stock exchange is not only about counting the financial report and technical analysis which can be predicted through historical graphic. Beyond that, the political situation will determine the investors in deciding whether to sell or buy stock in the exchange (Luhur, 2010).

Market reaction is shown by the emergence of price change from the pertinent securities. This reaction can be measured with return as the price change value or with abnormal return (Luhur, 2010; Khoirudin \& Faizati, 2014). When abnormal return is used as the indicator, it can be said that an announcement with information content will give abnormal return to the market. Conversely, an announcement without information content will not bring abnormal return to the market (Jogiyanto, 2003).

Number of research on market reaction towards political events have been conducted. Kabela and Hidayat (2009) studied the influence of presidential and vice presidential 
election event on 8 July 2009 in Indonesia towards abnormal return in Indonesia Stock Exchange. The result showed the existence of abnormal return average during the presidential election event on 8 July 2009. This result is different with a research done by Meidawati and Harimawan (2004) during the legislative election in 2004. Here, significant abnormal return average was not exist before and after the election.

Zaqi (2006) analyzed the effect of socialpolitical events in Indonesia towards capital market. The finding indicated that capital market reacted towards domestic economy and political events occurred during 1999-2003 period. It could be seen from the significant security return variability (SRV) around the event, i.e. every single day during the event period, which indicates that both economy and social-political events occur contain meaningful information content to the market.

Meanwhile, Herigita (2004) has done a research on capital market reaction towards Kuningan bombing event on 9 September 2004. The result showed the insignificant difference of security return variability (SRV) before and after the Kuningan bombing. It was caused by the investors' perception that the bombing has become a common event since early 2004, therefore, they did not respond the event much.

Meidawati and Harimawan (2004) conducted a research during the legislative election 2004 and found out the difference average value of stock trade volume before and after the election. Meanwhile, Luhut (2010) employed event study to figure out and analyze market reaction towards presidential election on 8 July 2009 using trade volume activity variable. The finding showed the existence of insignificant difference for the trade volume activity (TVA) in LQ 45 stocks listed in IDX before and after the 2009 presidential election

The research gap above has led the writer in conducting event study for companies' abnormal return, security return variability (SRV), and trade volume activity (TVA) in Indonesia Stock Exchange during the Working Cabinet announcement event. The event that the information content would be tested here is the Working Cabinet announcement event under the President Joko Widodo on 27 October 2014.

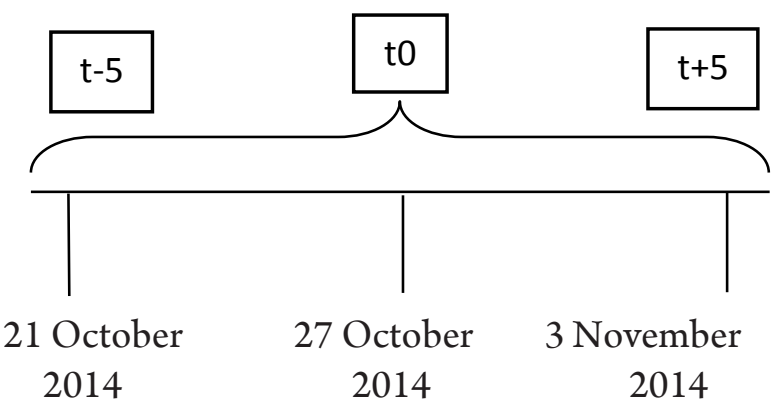

Security Return Variability (SRV) is used to find out whether the market aggregately valued an event as something informative or not. Means, the information causes changes on stock return distribution during the announcement (Utami, et al., 2004). Security Return Variability is also

Table 1. Research Gap Summary

\begin{tabular}{clcll}
\hline No & \multicolumn{1}{c}{ Researcher } & Year & \multicolumn{1}{c}{ Variable } & \multicolumn{1}{c}{ Finding } \\
\hline 1 & Kabela and Hidayat & 2009 & Abnormal return & Significant \\
2 & Meidawati and Harimawan & 2004 & Abnormal return & Insignificant \\
3 & Zaqi & 2006 & Security return variability & Significant \\
4 & Herigita & 2004 & Security return variability & Insignificant \\
5 & Meidawati and Harimawan & 2004 & Trade volume activity & Significant \\
6 & Luhur & 2010 & Trade volume activity & insignificant \\
\hline
\end{tabular}

Source: data processed (2015) 


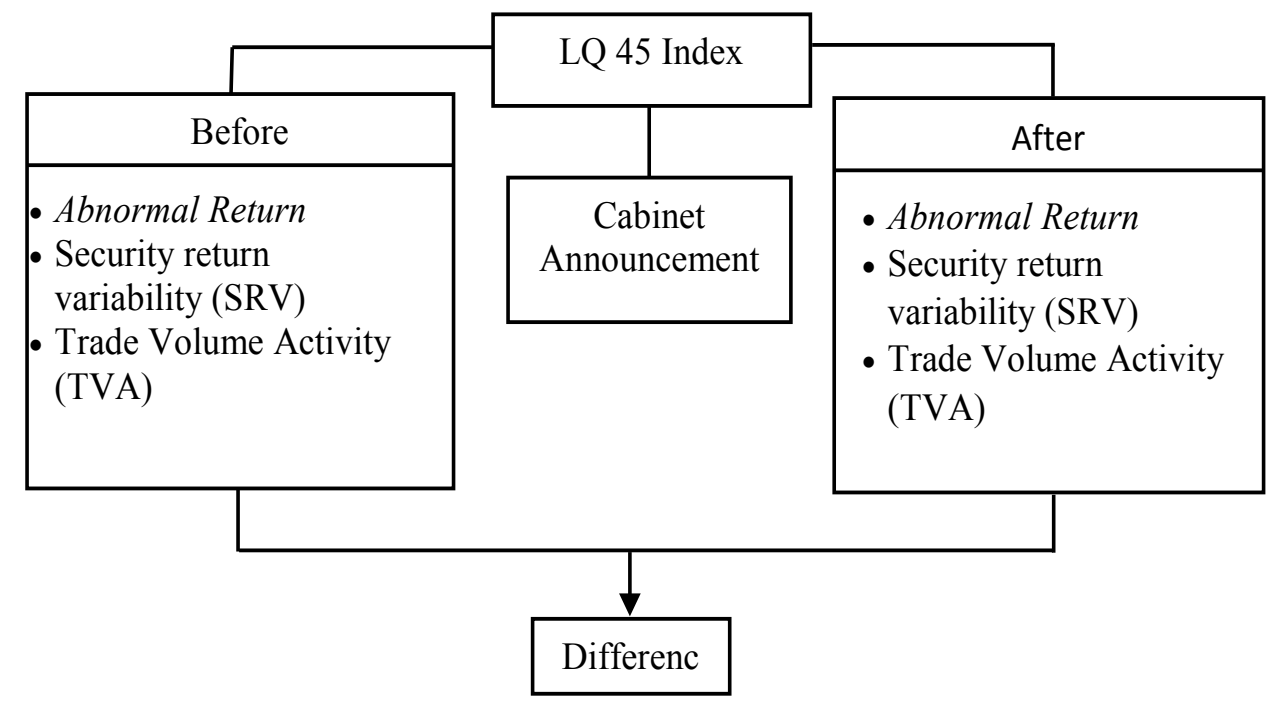

Figure 1. Theoretical Framework

applied to find out and measure whether or not the information causes difference on stock return distribution during the cabinet announcement.

Besides using the abnormal return and security return variability, capital market reaction can also be seen from the parameter of trade volume activity change in the market. When investors assume that an event contains information, the event will lead to the trading decision above the normal trading decision (Zaqi, 2006).

Based on Capital Market Act No 8 Year 1995 Article 1, "Capital market is defined as an activity which deals public offer and stock exchange, public company which is related to the stock published, and also institution and profession dealing with stock. According to Husnan, et al. (2005) when the capital market is efficient, then the announcement of an information or event will affect to (1) trading activity, (2) price variability and profit level, and (3) security price. Capital market is efficient towards an information item when the investor is impossible to consistently acquire a higher abnormal return than expected return in a normal investment condition by exploiting the information item (Nurhaeni, 2009). To see the market reaction towards the cabinet announcement, the writer compares abnormal return variable, security return variability (SRV), and Trade Volume (TVA) before and after the event. Theoretical framework of this research can be drawn in Figure 1.

The framework above has led to the following hypotheses:

$\mathrm{H} 1$ : There is different average for abnormal return before and after the Working Cabinet announcement.

$\mathrm{H} 2$ : There is different stock security return variability before and after the Working Cabinet announcement.

H3: There is different average for stock trade volume activity before and after the Working Cabinet announcement.

This research employed superior stocks as the object, the most active stocks and listed in the LQ 45 calculation during the research period. The use of LQ 45 stocks sampling in this research is based on the daily period used that requires liquid characteristic issuers with the biggest capitalization that the influence of an event can be immediately measured and relatively accurate.

\section{METHOD}

This research is an event study research which aims to see the capital market reaction towards the Working Cabinet announcement 
from President Joko Widodo through abnormal return approach, security return variability, and stock trade volume on stocks of companies included in the LQ 45 index. According to Tandelilin (2010), event study is a study that learn the market reaction towards a certain event that the information is published as an announcement and aims to measure the relation between events with the return level of a securities.

This research employed secondary data retrieved from www.idx.co.id and capital market laboratory of Economy Faculty of Universitas Negeri Semarang. The data sampling for this research applied purposive sampling which means population for this research sample was the population which met certain sample criteria based on the researcher's desire.

The sample which meets the criteria was as follows: (1) stock which was listed as issuers in Indonesia Stock Exchange (IDX) which included in LQ 45 company group during this research period from 20 October -3 November 2014, (2) actively traded during research period, (3) the stock data required were available for the research and (4) the company was absent in performing any corporate action like right issue, warrant, bonus share, stock dividend, and conversion option during the research period.

In this research, the company which performed corporate action was dropped out from the sample to avoid any bias effect occurred. Based on the filtered data, 44 companies were selected as the sample. One company, Indo Tambangraya Megah (ITMG), was dropped out of the sampling for doing a corporate action, i.e. sharing dividend on 30 October 2014. The final sample for this research can be seen as Tabel 2.

The period taken for this research was quite short, 5 days before and 5 days after the event, in order to avoid any bias effect occurred around the cabinet announcement event. The event here was the inauguration of the selected President and Vice President of Republic of Indonesia, Joko Widodo and Jusuf Kalla on 20 October 2014

Technique of analyzing the data employed in research was Paired Sample T-Test. Confidence level used here was 95\% with 5\% significance level or 0.05 . The acquired data were then processed with SPSS 19 and Microsoft Excel software programs. When abnormal data occurred on the research variables, the difference test would then not be analyzed using the Paired Sample T-test for the abnormal data but Wilcoxon Test. This test is a completion of the sign test. This test is carried out to test hypothesis of two sample comparative which have correlation when the data were in the ordinal (scaffold) form (Sugiyono, 2007).

The first hypothesis in this research was the existence of abnormal return average difference before and after the Working Cabinet announcement event. Stages in calculating hypothesis 1 were:

Tabel 2. Final sample research

\begin{tabular}{|c|c|c|}
\hline No & Code & Company Name \\
\hline 1 & AALI & Astra Agro Lestari Tbk \\
\hline 2 & $\mathrm{ADHI}$ & Adhi Karya Tbk \\
\hline 3 & $\mathrm{ADRO}$ & Adaro Energy Tbk. \\
\hline 4 & AKRA & AKR Corporindo Tbk \\
\hline 5 & ANTM & Aneka Tambang Tbk \\
\hline 6 & ASII & Astra Internasional Tbk \\
\hline 7 & ASRI & Alam Sutera Realty Tbk \\
\hline
\end{tabular}

Source: IDX statistics 
Anindya Ardiansari \& Arif Saputra / Capital Market's Reaction Towards 2014 Working...

Tabel 2. Countinous

\begin{tabular}{|c|c|c|}
\hline 8 & BBCA & Bank Central Asia Tbk \\
\hline 9 & BBNI & Bank BNI (Persero) tbk \\
\hline 10 & BBRI & Bank BRI (Persero) Tbk \\
\hline 11 & BBTN & Bank Tabungan Negara (Persero) Tbk \\
\hline 12 & BDMN & Bank Danamon Tbk \\
\hline 13 & BMRI & Bank Mandiri (Persero)Tbk \\
\hline 14 & BMTR & Global Mediacom Tbk \\
\hline 15 & BSDE & Bumi Serpong Damai Tbk \\
\hline 16 & CPIN & Charoen Pokphand Indonesia Tbk \\
\hline 17 & CTRA & Ciputra Development Tbk \\
\hline 18 & EXCL & XL Axiata Tbk \\
\hline 19 & GGRM & Gudang Garam Tbk \\
\hline 20 & HRUM & Harum Energy Tbk \\
\hline 21 & ICBP & Indofood CBP Sukses Makmur Tbk \\
\hline 22 & INCO & Vale Indonesia Tbk \\
\hline 23 & INDF & Indofood Sukses Makmur Tbk \\
\hline 24 & INTP & Indocement Tunggal Prakasa Tbk \\
\hline 25 & JSMR & Jasa Marga (Persero) Tbk \\
\hline 26 & KLBF & Kalbe Farma Tbk \\
\hline 27 & LPKR & Lippo Karawaci Tbk \\
\hline 28 & LPPF & Matahari Department Store Tbk \\
\hline 29 & LSIP & PP London Sumatera Indonesia Tbk \\
\hline 30 & $\mathrm{MNCN}$ & Media Nusantara Citra Tbk \\
\hline 31 & PGAS & Perusahaan Gas Negara (Persero) Tbk \\
\hline 32 & PTBA & Tambang Batubara Bukit Asam (Persero) Tbk \\
\hline 33 & РTPP & PP (Persero) Tbk \\
\hline 34 & PWON & Pakuwon Jati Tbk \\
\hline 35 & SCMA & Surya Citra Media Tbk \\
\hline 36 & SMGR & Semen Indonesia (Persero) Tbk \\
\hline 37 & SMRA & Sumarecon Agung Tbk \\
\hline 38 & TAXI & Express Transindo Utama Tbk \\
\hline 39 & TBIG & Tower Bersama Infrastructure Tbk \\
\hline 40 & TLKM & Telkom Indonesia Tbk \\
\hline 41 & UNTR & United Tractors Tbk \\
\hline 42 & UNVR & Unilever Indonesia Tbk \\
\hline 43 & WIKA & Wijaya Karya (Persero) Tbk \\
\hline 44 & WSKT & Waskita Karya (Persero) Tbk \\
\hline
\end{tabular}

Source: IDX statistics 
Calculating real return for each stock

$$
R_{\text {it }}=\left(\frac{P_{\text {it }}-P_{\text {it }}-\mathrm{t}}{P_{\text {it }}-\mathrm{t}}\right)
$$

Note:

$\mathrm{R}_{\mathrm{it}}=$ Real return of stock $\mathrm{i}$ day $\mathrm{t}$

$\mathrm{P}_{\mathrm{it}}=$ stock price $\mathrm{i}$ day $\mathrm{t}$

$\mathrm{P}_{\mathrm{it}-\mathrm{t}}=$ stock price $\mathrm{i}$ day $\mathrm{t}-1$

Calculating Expected ReturnThe marketadjusted model regards the best predictor in estimating return of a securities is the market index return of the certain time.

$$
E(R i t)=\frac{L Q 45 t}{L Q 45 t-1}
$$

Note:

$\mathrm{E}$ (Rit) $=$ Expected return

LQ 45t $=$ LQ 45 index at $\mathrm{t}$ time

LQ $45 \mathrm{t}-1=\mathrm{LQ} 45$ index at $\mathrm{t}-1$ time

Calculating Abnormal Retur The abnormal return calculation employed the following formulation:

$$
\text { ARit }=R_{i t}-E(R i t)
$$

Note:

Arit $=$ Abnormal Return of stock i day $t$

$\mathrm{R}_{\mathrm{it}}=$ Real Return of stock $\mathrm{i}$ day $\mathrm{t}$

$E\left(R_{i t}\right)=$ Expected Return of stock i day $t$

Conducting abnormal return significance test on the event period. Abnormal return mean for day 5 was calculated as follows:

$$
A A R t=\frac{\sum_{i=l}^{n}}{n} A R, i, t
$$

Note:

AARt $=$ Abnormal return mean

$\mathrm{n} \quad=$ Number of companies being studied
Creating statistical comparison of AARt before and after the cabinet announcement event by using Paired Sample T-Test. Calculating the security return variability (SRV) of each stock

$$
\text { SRVi, } \mathrm{t}=\frac{(A R i, t)^{2}}{V(A R i)}
$$

Note:

SRVi,t $=$ Stock return variability of stock i day $\mathrm{t}$

ARi,t = Abnormal return of stock $\mathrm{i}$ day $\mathrm{t}$

$\mathrm{V}(\mathrm{ARi})=$ Variance of abnormal return of stock at the estimated period

Calculating SRV mean

$$
\text { ASRV } i, t=\frac{\sum_{k=1}^{n} S R V i, t}{n}
$$

Note:

ASRVi,t $=S R V$ mean for event day $\mathrm{t}$

SRVi,t = SRV stock $\mathrm{i}$ for event day $\mathrm{t}$

$\mathrm{n}=$ Number of stock sample

Creating statistical comparison of ASRVit before and after the cabinet announcement event by using Paired Sample T-Test. To calculate trade volume activity of stock i period $\mathrm{t}$, the following formulation (Suryawijaya \& Setiawan, 1996) was employed:

$$
\text { TVAit }=\frac{\sum \text { stock } i \text { traded at day } t}{\sum \text { stock } i \text { circulated at day } t}
$$

Calculating trade volume activity mean of all stocks used as the sample before and after the event (Suryawijaya \& Setiawan, 1996):

$$
\begin{aligned}
& A T V A=\frac{\sum_{t-5}^{t-1}}{5} T V A \text { before } \\
& A T V A=\frac{\sum_{t-5}^{t-1}}{5} T V A \text { after }
\end{aligned}
$$


Anindya Ardiansari \& Arif Saputra / Capital Market’s Reaction Towards 2014 Working...

Testing trade volume activity difference mean of all stocks used as the sample during five days before and five days after the event by using Wilcoxon Test.

\section{RESULT AND DISCUSSIONS}

Table 3. Indicates that abnormal return average before and after the cabinet announcement event was distributed normally with the significance probability at 0.355 and 0.797 above a (0.05). Therefore, the next test to be carried out is the Paired Sample T-Test test (Ghozali, 2011). Table 4. The OneSample Kolmogorov-Smirnov Data Normality Test of Stock Security Return Variability Before and After the Cabinet Announcement Event Table 4 indicated that security return variability average before and after the cabinet announcement event was distributed normally with significance probability at 0.983 and 0.787 above a (0.05). The result was then tested with Paired Sample T-Test (Ghozali, 2011).

Table 5. The One-Sample KolmogorovSmirnov Data Normality Test of Trade Volume Activity Average Before and After the Cabinet Announcement Event Table 5 indicated that the normality test using KolmogorovSmirnov test towards trade volume activity variable resulted 0.011 and 0.007 significance probability score or below a (0.05). An abnormality was exist for the trade volume activity variables before and after the cabinet announcement. Next, the Paired Sample T-Test was not employed to test hypothesis 3, but with Wilcoxon test (Dwipayana, 2011).

Table 3. One-Sample Kolmogorov-Smirnov Test

\begin{tabular}{llll}
\hline & & AAR_before & AAR_after \\
\hline $\mathrm{N}$ & & 44 & 44 \\
Normal Parameters $^{\mathrm{a}}$ & Mean & .0008994 & .0089274 \\
& Std. Deviation & .00596576 & .00871302 \\
Most Extreme & Absolute & .140 & .098 \\
Differences & Positive & .106 & .086 \\
Kolmogorov-Smirnov Z & Negative & -.140 & -.098 \\
Asymp. Sig. (2-tailed) & & .928 & .647 \\
\hline
\end{tabular}

a. Test distribution is Normal.

Source: data processed (2015)

Table 4. One-Sample Kolmogorov-Smirnov Test

\begin{tabular}{llll}
\hline & & ASRV_before & ASRV_after \\
\hline $\mathrm{N}$ & & 44 & 44 \\
Normal Parameters $^{\mathrm{a}}$ & Mean & .9651381 & .9790628 \\
& Std. Deviation & .43324662 & .49077150 \\
Most Extreme & Absolute & .070 & .098 \\
Differences & Positive & .070 & .098 \\
& Negative & -.070 & -.098 \\
Kolmogorov-Smirnov Z & & .463 & .653 \\
Asymp. Sig. (2-tailed) & & .983 & .787 \\
\hline
\end{tabular}

a. Test distribution is Normal.

Source: data processed (2015) 
Table 5. One-Sample Kolmogorov-Smirnov Test

\begin{tabular}{llll}
\hline & & ATVA_before & ATVA_after \\
\hline $\mathrm{N}$ & & 44 & 44 \\
Normal Parameters $^{\mathrm{a}}$ & Mean & .0016242 & .0017403 \\
& Std. Deviation & .00165920 & .00219737 \\
Most Extreme & Absolute & .244 & .254 \\
Differences & Positive & .244 & .248 \\
Kolmogorov-Smirnov Z & Negative & -.191 & -.254 \\
Asymp. Sig. (2-tailed) & & 1.618 & 1.685 \\
\hline
\end{tabular}

a. Test distribution is Normal.

Source: data processed (2015)

Table 6. Abnormal Return

Paired Samples Test

\begin{tabular}{|c|c|c|c|c|c|c|c|c|}
\hline & \multicolumn{5}{|c|}{ Paired Differences } & \multirow{3}{*}{\multicolumn{2}{|c|}{$\mathbf{T}$}} & \multirow{3}{*}{$\begin{array}{c}\text { Sig. } \\
\text { (2-tailed) }\end{array}$} \\
\hline & \multirow[t]{2}{*}{ Mean } & \multirow{2}{*}{$\begin{array}{c}\text { Std. } \\
\text { Deviation }\end{array}$} & \multirow{2}{*}{$\begin{array}{l}\text { Std. Error } \\
\text { Mean }\end{array}$} & \multicolumn{2}{|c|}{$\begin{array}{c}95 \% \text { Confidence Inter- } \\
\text { val of the Difference }\end{array}$} & & & \\
\hline & & & & Lower & Upper & & & \\
\hline $\begin{array}{l}\text { Pair } 1 \text { AAR_- } \\
\text { before- } \\
\text { AAR after }\end{array}$ & $-8.02800728 \mathrm{E}-3$ & .00981636 & .00147987 & -.01101245 & -.00504356 & -5.425 & 43 & .000 \\
\hline
\end{tabular}

Source: data processed (2015)

Table 7. Scurity Return Variability

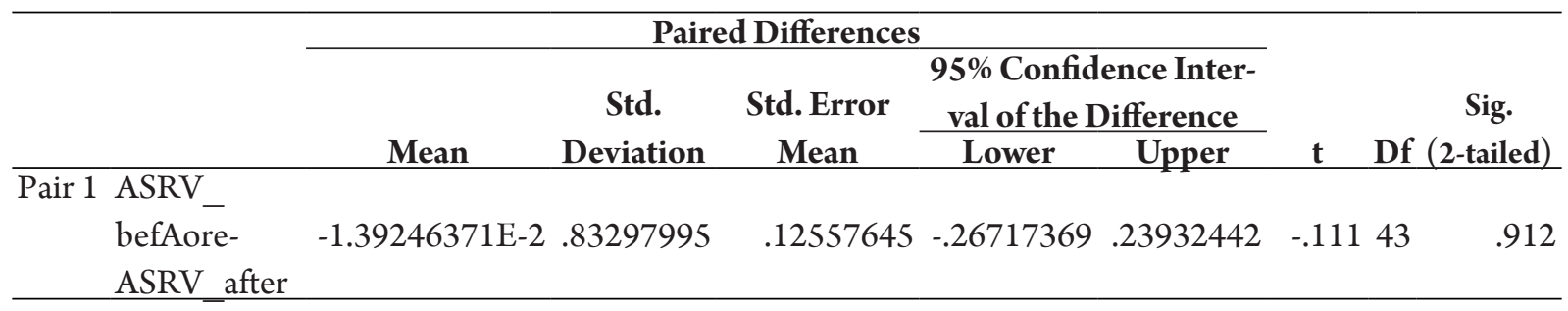

Source: data processed, (2015)

The normality test result used OneSample Kolmogorov-Smirnov Test indicated that the abnormal return and security return variability average data before and after the cabinet announcement event were distributed normally and appropriate to be used in the hypothesis test by employing difference test for the related sample (Paired Sample T-Test). However, the trade volume activity variable was not normally distributed. Thus, the trade volume activity variable was tested with Wilcoxon test.

\begin{abstract}
Abnormal Return
The test showed that the significance was valued at 0.000 which means below the determined probability level at 0.05 . It can be said that $\mathrm{H} 1$ is accepted. It means that there was significant effect towards abnormal return difference before and after the cabinet announcement on the companies listed in LQ 45. The existence of this significant difference means that market reacted with the cabinet
\end{abstract}


Table 8. Trade Volume Activity

Test Statistics ${ }^{\mathrm{b}}$

\begin{tabular}{lc}
\hline & ATVA_after-ATVA_before \\
\hline $\mathrm{Z}$ Asymp. Sig. (2-tailed) & $-.303^{\mathrm{a}}$ \\
& .762 \\
a. Based on positive ranks. &
\end{tabular}

a. Based on positive ranks.

b. Wilcoxon Signed Ranks Test

Source: (Processed data, 2015)

announcement event. Investors believed that the cabinet announcement with the minister composition in it would bring good news to the capital market climate in Indonesia.

\section{Security Return Variability}

The test showed that the significance was valued at 0.912 which means above the determined probability level at a (0.05). It can be said that $\mathrm{H} 2$ is rejected. It means that significant effect towards the changes of security return variability mean before and after the cabinet announcement on the companies listed in LQ 45 was absent (Ghozali, 2011). The absence of the significant difference means that market reacted with the cabinet announcement event, but did not bring equal profit to the companies listed in LQ45.

\section{Trade Volume Activity}

The following table showed the processed data of the stock trade volume activity mean before and after the cabinet announcement event by using Wilcoxon Test.The table showed that the significance was valued at 0.762 which means far above the probability level at 0.05 . Based on the processed data, it can be concluded that $\mathrm{H} 3$ is rejected. It means that there was no significant improvement between trade volume activity before and after the cabinet announcement. In other words, the cabinet announcement event gave insignificant effect towards the stock trade volume change.

\section{CONCLUSION}

Based on the discussions done in the previous chapters, this research which aims to examine abnormal return, security return variability, and trade volume activity differences before and after the Working Cabinet announcement event concluded that the unavailability of abnormal return difference before and after the cabinet announcement since the significance score was at 0.000 which was below the determined probability level $\bigotimes$ at 0.05 . It means that there is a significant effect towards the abnormal return difference before and after the cabinet announcement on the companies listed in LQ 45.

The absence of security return variability difference before and after the cabinet announcement. It can be seen from the analysis result during the observation period which showed the significance score was at 0.912 and higher that $\mathbb{Q}(0.05)$ which means that there was no security return variability difference between five days before and five days after the cabinet announcement event. The absence of trade volume activity difference before and after the cabinet announcement. It can be seen from the analysis result during the observation period which showed the significance score was at 0.762 and higher than a (0.05) which means that there was no trade volume activity difference between five days before and five days after the cabinet announcement.

Based on the research results, some suggestions can be given to the relevant parties are as follows mainly for the investors, not all 
information at the capital market is a valuable information, therefore, investors must be very careful in selecting and analyzing relevant information to be parts of their consideration in making decision. These research results give valuable input for issuers that the cabinet announcement event can affect the market; therefore, investors must be very careful in selecting and analyzing domestic current events, especially beyond the economy field which might cause changes in price, profit level, and trade volume activity. For the next researchers, it is hoped that this research output can be used as a reference and note for the next research, particularly on the field of event study research.

\section{REFERENCES}

Dwipayana, K. 2011. Dampak Peristiwa Pengesahan UU No 25 Tahun 2007 Tentang Penanaman Modal pada Harga Saham di Bursa Efek Indonesia. Skripsi. Surakarta: Universitas Sebelas Maret.

Ghozali, I. 2011. Aplikasi Analisis Multivariate dengan Program IBM SPSS 19. Semarang: Badan Penerbit Universitas Diponegoro.

Herigita K. 2004. Reaksi Pasar Modal Indonesia Terhadap Peristiwa Non Eonomi (Studi Kasus Peristiwa Bom Kuningan 9 September 2004). Jurnal TPSDP. Jember: Universitas Jember.

Husnan, S., Mamduh, H \& Wibowo, A. 1996. Dampak Pengumuman Laporan Keuangan Terhadap Kegiatan Perdagangan Saham dan Variabilitas Tingkat Keuntungan. Kelola. 5 (11). Yogyakarta: Universitas Gajah Mada.

Jogiyanto, H. M. 2003. Teori Portofolio dan Analisis Investasi. Third Edition. Yogyakarta: BPFE.

Listiana \& Ghozali. 2009. Analisis Reaksi Pasar Modal Terhadap Pengumuman Right Issue Di Bursa Efek Jakarta (BEJ). Wacana. 22 (4).
Luhur, S. 2009. Reaksi Pasar Modal Indonesia Seputar Pemilihan Umum 8 Juli 2009 pada Saham LQ-45. Jurnal Keuangan dan Perbankan. 14 (2).

Meidawati, N \& Harimawan, M. 2004. Pengaruh Pemilihan Umum Legislatif Indonesia Tahun 2004 Terhadap Return Saham dan Volume Perdagangan Saham LQ-45 di PT. Bursa Efek Jakarta (BEJ). Sinergi Kajian Bisnis dan Manajemen. 7 (1).

Khoirudin, M \& Faizati, E. R. 2014. Reaksi pasar terhadap dividend announcement perusahaan yang sahamnya masuk daftar efek syariah. Jurnal Dinamika Manajemen. 3 (2).

Nurhaeni, N. 2009. Dampak Pemilihan Umum Legislatif Indonesia Tahun 2009 Terhadap Abnormal Return dan Aktivitas Volume Perdagangan Saham di BEI. Tesis. Semarang: Universitas Diponegoro.

Pemerintah RI, Undang-Undang No. 8 Tahun 1995 Tentang Pasar Modal.

Pronayuda, T. 2006. Reaksi Pasar Terhadap Peristiwa Pengumuman Kabinet Indonesia Bersatu”. Skripsi. Yogyakarta: Universitas Islam Indonesia.

Sugiyono. 2007. Statistik Nonparametris untuk Penelitian. Bandung: Alfabeta.

Suryawijaya, M. A \& Setiawan, F.A. 1998. Reaksi Pasar Modal Indonesia terhadap Peristiwa Politik Dalam Negeri, Event Studi pada Peristiwa 27 Juli 1996. Kelola. 18 (7).

Tandelilin, E. 2010. Portofolio dan Investasi: Teori dan Aplikasi. Yogyakarta: Kanisius.

Utami, T. N., Idris, S \& Maski, G. 2004. Dampak Pengumuman Stock Split Terhadap Return, Variabilitas Tingkat Keuntungan, dan Volume Perdagangan Saham Studi pada Perusahaan Manufaktur yang Terdaftar di BEJ Tahun 1997-1999. Jurnal Aplikasi Manajemen. 2 (3).

Zaqi, M. 2006. Reaksi Pasar Modal Indonesia Terhadap Peristiwa-Peristiwa Ekonomi dan Peristiwa-Peristiwa Sosial-Politik dalam Negeri. Tesis. Semarang: Universitas Diponegoro. 